\title{
O Objeto de museu como documento: um panorama introdutório
}

\author{
Maria Lucia de Niemeyer Matheus Loureiro \\ Doutora; Museu de Astronomia e Ciências Afins, Rio de Janeiro, RJ, Brasil; \\ 1.niemeyer@gmail.com
}

\begin{abstract}
Resumo: O artigo apresenta um panorama das discussões sobre o objeto como documento na Ciência da Informação e na Museologia, identifica e analisa pontos convergentes e divergentes nas duas disciplinas. Estudo exploratório fundamentado em pesquisa bibliográfica. É ressaltada a contribuição da Ciência da Informação, que reconheceu o objeto como documento décadas antes das discussões promovidas pela Museologia. São abordadas as discussões em torno do objeto de museu como documento no âmbito da Museologia (considerada por alguns autores um marco da maturidade teórica da disciplina) e a posterior rejeição da noção. É observado um esforço de apagamento do passado da Museologia por alguns de seus influentes teóricos.
\end{abstract}

Palavras-chave: Documento. Objeto de museu. Ciência da Informação. Museologia.

\section{Introdução}

A compreensão do objeto como documento percorreu direções diferentes e caminhos independentes na Museologia e Ciência da Informação (CI); ao acompanhar seu percurso na Museologia, esperamos iluminar questões pouco exploradas e abrir horizontes para futuras pesquisas. Este artigo foi desenvolvido no âmbito de um projeto de pesquisa que aborda os processos de musealização a partir de um enfoque informacional, e que tem como fio condutor o pressuposto de que objetos de museus são tornados documentos através de práticas e processos de musealização.

Para a pesquisa bibliográfica, foram selecionadas obras de autores que se debruçaram sobre o tema tratado, privilegiando (mas não se limitando a) a produção do Comitê Internacional de Museologia (ICOFOM), órgão ligado ao Conselho Internacional de Museus (ICOM), além de autores com atuação 


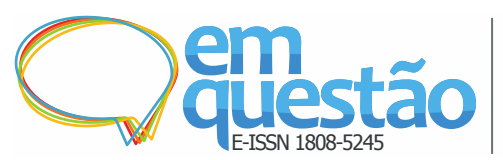

expressiva no Comitê. A adoção desse critério é justificada pelo fato de o ICOFOM se apresentar como a principal instância internacional de discussão sobre a Museologia, e de alguns de seus mais influentes autores conferirem um papel central à questão aqui abordada.

Para Ivo Maroević ${ }^{1}$ (1998), o reconhecimento do objeto de museu como documento é o marco inicial do que ele chamou "fase teórico-sintética" (MAROEVIĆ, 1998, p. 85) no desenvolvimento da disciplina. As reflexões sobre o tema ganharam impulso e espaço no ICOFOM. Criado em 1977, os encontros e publicações do Comitê buscaram legitimar a Museologia como disciplina científica autônoma e, segundo Suely Ceravolo, "[...] moldar teoricamente a área almejando cunhar pressupostos para suprir o que era tido como um vazio." (CERAVOLO, 2004, p. 238). É digno de nota, entretanto, o desconhecimento da realidade museológica mundial pelo ICOFOM, o que é ilustrado pela polêmica relativa ao uso dos termos museologia e museólogo. Conforme Davallon (1997, p. 25), o termo "museologia" era pouco utilizado na França, entre profissionais de museu, na última década do século XX, “[...] salvo em sua forma adjetivada museológico [...]”, para designar tudo o que pertence à esfera dos museus. Ressaltando o caráter não oficial das decisões do ICOFOM, Jesús Pedro Lorente (2012, p. 61) registra que o comitê, por influência do museólogo polonês Wojciech Gluzinski, recomendou o uso do termo museólogo exclusivamente para os teóricos, embora vários países, entre os quais o Brasil, o adotassem para se referir aos profissionais de museus ${ }^{2 .}$ Isto sinaliza um menosprezo pelos aspectos práticos inerentes à disciplina e um esforço para estabelecer balizas e demarcar um campo permanentemente qualificado como em processo de construção / consolidação.

Ainda de acordo com Lorente (2012, p. 62), a despeito da importância inegável dos eventos do ICOFOM, que teriam contribuído para a criação de uma "comunidade científica internacional", a limitada tiragem das publicações restringiu seu acesso ${ }^{3}$, fazendo com que só se tornassem conhecidas, bem mais tarde, em sua versão digital: 
[...] A prova é que durante décadas não tiveram nenhum impacto na bibliografia museológica, pois só citavam as atas do ICOFOM alguns poucos membros especialmente motivados, que assistiam a quase todas as reuniões. Os demais, mesmo quando se animavam a participar de algum seminário ou conferência, ignoravam o tratado nos anteriores, de modo que durante anos a museologia parecia uma disciplina em plena reinvenção: em cada simpósio ou conferência se produziam novos discursos, os quais não eram construídos a partir do argumentado anteriormente. (LORENTE, 2012, p. 62).

Os encontros promovidos pelo ICOFOM iluminam guerras de posição e disputas em torno de um tema sobre o qual, ainda hoje, não há consenso na disciplina, e que é marcado por idas e vindas em um terreno acidentado. A tiragem limitada das publicações, que podem ser caracterizadas como literatura cinzenta $^{4}$, manteve os trabalhos apresentados e as discussões travadas nos encontros do comitê pouco acessíveis por longo tempo. A digitalização das publicações, disponíveis apenas a partir de 2011 na página do ICOFOM, possibilitou o acesso a textos reveladores de discussões cujos originais, de outra forma, permaneceriam desconhecidos. Esta é a justificativa para o grande número de citações literais neste artigo.

$\mathrm{Na} \mathrm{CI}$, a contribuição dos teóricos da Documentação e o papel pioneiro de Paul Otlet (1934) e de Suzanne Briet (1951) sobre o tema são amplamente reconhecidos. Redescobertos no final do século XX, os autores e sua obra foram retomados pela CI, assim como o conceito de documento. Tais trabalhos foram, por longo tempo, ignorados no campo da Museologia, no qual ressaltamos a inquestionável influência exercida pelo autor tcheco Zbynek Stránský ${ }^{5}$, não apenas na afirmação do objeto como documento, mas também na posterior refutação da ideia.

\section{Objeto de museu como documento: um olhar da ciência da informaçãa ${ }^{6}$}

O nome documentação foi empregado pela primeira vez por Paul Otlet em 1903 no artigo Les sciences bibliographiques et de la documentation ${ }^{7}$ (ORTEGA, 2009, p. 5-6) para designar um novo campo de estudo voltado não apenas aos documentos escritos e gráficos, mas também a objetos dotados de "valor 


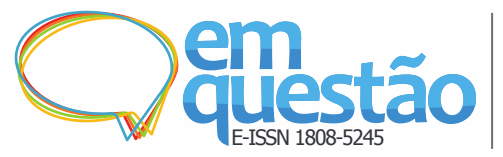

documental" (RAYWARD, 1990, p. 3). No referido artigo, apontado por FayetScribe (2001 $\mathrm{apud}^{8}$ ORTEGA, 2009, p. 6) como o texto "fundador" de sua obra, Otlet (1990, p. 76) aponta como "fontes de nosso conhecimento" (ou “documentos") os próprios objetos físicos, os monumentos e as fontes escritas.

Em sua obra mais celebrada, publicada em 1934 e intitulada Traité de Documentation, Otlet incluiu, ao lado dos livros propriamente ditos, que "[...] constituem em seu conjunto a memória materializada da humanidade [...]" (OTLET, 1934, p. 43, tradução nossa), o que denomina "substitutos do livro", considerando que "[...] as próprias coisas materiais (objetos) podem ser vistas como documentos, uma vez erigidas como elementos sensíveis diretos de estudo ou prova de uma demonstração." (OTLET, 1934, p. 217, tradução nossa, grifo nosso).

Para Niels Windfeld Lund (2009, p. 6), a maior contribuição teórica para a discussão sobre documentos foi a da documentalista francesa Suzanne Briet que, como Otlet, buscou resolver problemas práticos e aperfeiçoar o trabalho da Documentação, mas também teorizar e problematizar o campo. Em sua influente obra Qu'est-ce que la documentation?, Briet propõe uma redefinição de documento como "[...] todo indício concreto ou simbólico, conservado ou registrado com os fins de representar, reconstituir ou provar um fenômeno físico ou intelectual $[\ldots]$ ".. Para problematizar o conceito e seu argumento, questiona: "Uma estrela é um documento? Um seixo levado pela torrente é um documento? Um animal vivo é um documento?”. A todas essas perguntas responde negativamente, acrescentando: "Mas são documentos as fotografias e os catálogos de estrelas, as pedras em um museu de mineralogia, os animais catalogados e expostos em um zoo.” (BRIET, 1951, p. 7, tradução nossa).

A redescoberta das obras de Otlet e Briet nas últimas décadas do século $\mathrm{XX}$ foi determinante para o florescimento de estudos sobre o conceito de documento. Retomando os termos "documentação" e "documentologia" utilizados quase meio século antes por Otlet (1934, p. 9), Jean Meyriat define o documento como "[...] um objeto que dá suporte à informação, serve para comunicá-la e é durável [...]” (MEYRIAT, 1981, p. 51, tradução nossa). Além dos "documentos por intenção", criados com o objetivo de documentar, o autor 


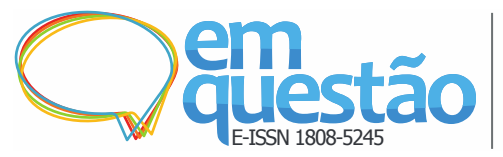

destaca os "documentos por atribuição", objetos tornados documentos por aquele que busca uma informação e reconhece neles um significado. Isso implica em afirmar que qualquer coisa, independente de sua função original, pode ser tornada documento. Referindo-se especificamente a objetos de museu, como os esqueletos do Museu de História Natural ou os trajes camponeses no Museu de Artes e Tradições Populares ${ }^{9}$, o autor observa que os primeiros “[...] preservam e fornecem informações sobre a fauna da era quaternária [...]", enquanto os segundos "[...] sobre os modos de vida e os costumes da França Rural no século XVIII [...]” (MEYRIAT, 1981, p. 52, tradução nossa). Embora o objeto tenha duas origens possíveis, o emissor e o receptor, é a intenção do segundo que prevalece:

Se o desejo de fornecer informações não for correspondido pelo destinatário, a informação permanece virtual. O objeto [...] não é ainda um documento. Poderá sê-lo mais tarde, quando uma pergunta lhe será colocada e ativará esta informação. (MEYRIAT, 1981, p. 54, tradução nossa).

Lamentando que Briet não tenha especificado suas fontes, Lund (2009) aponta uma possível influência da semiótica de Charles S. Peirce, particularmente no que se refere à classificação dos signos em ícone, índice e símbolo. Signos podem manter com as coisas relação de semelhança (ícone), conexão física (índice) ou mental (símbolo), o que explicaria por que, em alguns casos, Briet abordou documentos como signos concretos e, em outros, como simbólicos. Michael Buckland (1997), por sua vez, deduziu do conceito de documento proposto por Briet os seguintes critérios:

(1) Há materialidade: apenas objetos e signos físicos;

(2) Há intencionalidade: pretende-se que o objeto seja tratado como documento;

(3) Os objetos devem ser processados: Eles devem ser tornados documentos; e, supomos,

(4) Há uma posição fenomenológica: O objeto é percebido como documento. (BUCKLAND, 1997, p. 806, tradução nossa). 


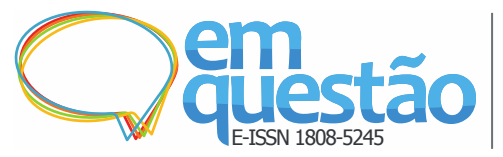

Mais do que a redefinição do conceito de documento, Frohmann destacou em Briet sua força argumentativa e a projeção do conceito em diferentes situações. Se um animal se torna documento no zoológico é porque este é um lugar em que o animal se torna disponível para apoiar ou documentar uma afirmação: "A importância do lugar, para considerar que alguma coisa é um documento ou tem propriedades documentais, não é tão estranha quando pensamos em objetos de museu.”. (FROHMANN, 2009, p. 297, tradução nossa).

\section{O Objeto de museu como documento: um olhar da Museologia}

No Brasil, a discussão do objeto como documento remonta à década de 1950 e aos trabalhos de Florisvaldo dos Santos Trigueiros (1955; 1956). Leitor de Paul Otlet, a quem cita em seu livro Museus: sua importância na educação do povo (1956), o autor defende uma documentação dinâmica, que assegure o livre acesso aos documentos, e concebe o museu como órgão de documentação, ao lado de bibliotecas, arquivos, estações de rádio e televisão. Estes aplicariam técnicas de documentação em seu trabalho de criar, coletar, classificar, conservar, registrar e divulgar o documento (TRIGUEIROS, 1956, p. 11).

Cabe aqui uma menção especial ao prefácio da obra, de autoria de Espírito Santo Mesquita que, após fazer referência às recentes reflexões de Suzanne Briet sobre documento, esclarece que Trigueiros incluía a museografia entre as técnicas de documentação e defendia a tese de que "[...] o museu integra o sistema de que a biblioteca faz parte e nesse particular estabelece como premissa o verdadeiro conceito moderno de documentação [...]” (MESQUITA, 1956, p. 2).

De acordo com autores vinculados ao ICOFOM, as abordagens ao objeto de museu como documento remontariam a trabalhos desenvolvidos desde a década de $1960^{10}$. Em 1970, foi publicado o artigo intitulado Pojam muzeologije (O conceito de Museologia), de autoria de Stránský, no periódico Museologiza, de Zagreb (antiga Iugoslávia, atual Croácia). No artigo, citado por Maroević (2004), o objeto de museu é definido como “[...] um objeto da realidade, uma 


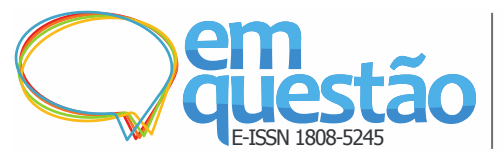

parte do patrimônio cultural móvel. Transferido para o museu, o objeto se torna um documento daquela realidade da qual foi selecionado." (STRÁNSKÝ, 1970 $\operatorname{apud}^{11}$ MAROEVIĆ, 2004, p. 24, tradução nossa, grifo nosso).

A partir de 1979, quando passou a colaborar com o ICOFOM, “[...] o pensamento de Stránský avança para além dos antigos países do leste europeu [...]" (BARAÇAL, 2008, p. 3). Até então, sua obra tivera pouca penetração fora dos países do Bloco Socialista, não apenas em virtude da evidente barreira da língua, como também por questões geopolíticas.

De acordo com Bruno Brulon, Stránský “[...] seria responsável por deslocar o objeto da Museologia do museu, como instituição historicamente fundada, para a musealidade - entendida como um 'valor documental especifico'." (BRULON, 2017, p. 410, grifo do autor). A existência da Museologia como disciplina científica independente seria inicialmente justificada por Stránský a partir dos objetos de museu - museália. Segundo Mensch (1992), o termo museália (musealium) foi cunhado por Stránský em 1969 e condensado em 1985, em um Encontro do ICOFOM realizado em Zagreb. A determinação do objeto de museu, segundo palavras do próprio Stránský, viria de:

[...] uma relação específica entre homem e realidade ('musealidade') [...], motivada pelo esforço para proteger contra as mudanças naturais e a ruína os objetos da realidade natural e social que podem representar de forma ideal valores cuja aplicação e conservação sejam de interesse para o enriquecimento e desenvolvimento da cultura e da sociedade como um todo.

Esses objetos como objetos de museu potenciais /'museália'/ são, do ponto de vista ontológico, idênticos ao objeto em geral mas no nível do sentido desempenham funções novas, a de testemunhos autênticos, documentos [...] de fatos naturais ou sociais. (STRÁNSKÝ, 1985, p. 107, tradução nossa, grifo nosso).

Para Stránský (1974 apud ${ }^{12}$ SCHREINER, 1980, p. 39), o museu seria "[...] uma instituição documentária que acumula, preserva e comunica testemunhos autênticos da realidade objetiva [...]", cujo objeto seria a "musealidade", a qual define como um “[...] valor documental específico de objetos concretos perceptíveis da natureza e sociedade [...]”. 


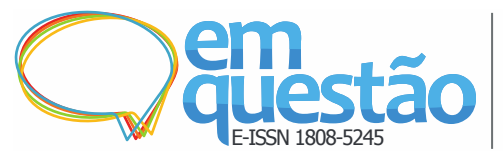

Ao menos até a década de 1980, a abordagem de Stránský ao objeto de museu é fortemente centrada no conceito de documento (embora essa orientação tenha mudado radicalmente na década seguinte). Algumas de suas reflexões sugerem, inclusive, a possibilidade de um contato com a obra de Suzanne Briet: "Uma borboleta capturada e fixada com um alfinete é uma testemunha direta, documento da existência dessa borboleta; ao mesmo tempo, ela testemunha não somente ela própria, mas também a espécie que representa." (STRÁNSKÝ, 1985, p. 107, tradução nossa, grifo nosso).

A compreensão do objeto como documento é quase hegemônica nos primeiros anos do ICOFOM. Nas palavras de Jelínek, fundador do Comitê:

\begin{abstract}
Museus conservam alguns importantes objetos - documentos. Eles formam coleções que devem fornecer amostras representativas e, portanto, informações tão objetivas quanto possível. A formação dessas coleções de objetos, que são fontes originais, inesgotáveis de informação, é o cerne da museologia científica, que não é nem pode ser duplicada por qualquer outro ramo da ciência. (JELÍNEK, 1980, p. 4, tradução nossa, grifo nosso).
\end{abstract}

Ao abordar o caráter interdisciplinar da Museologia, Gregorová ressalta sua conexão inevitável com os objetos de museu, ou seja, com os "[...] documentos materiais do desenvolvimento da natureza e sociedade [...]", dotados de "[...] valor documental ou valor de museu, no sentido próprio do termo.” (GREGOROVÁ, 1981, p. 35, tradução nossa, grifos da autora).

Apesar do baixo impacto imediato da produção do ICOFOM (LORENTE, 2012, p. 62), questão já apontada na introdução, algumas reflexões sobre o objeto como documento chegaram ao Brasil, na década de 1980, através da brasileira Waldisa Rússio ${ }^{13}$, membro do ICOFOM e participante dos encontros do Comitê em seus primórdios. Para a autora, o objeto de estudo da Museologia seria o "[...] fato de museu, ou o fato museológico [...], relação profunda entre o homem, sujeito cognoscente, e o objeto: a parte da realidade à qual o homem pertence e sobre a qual tem o poder de agir." (RÚSSIO, 1981, p. 56, tradução nossa, grifos da autora). Admite, entretanto, que essa relação 


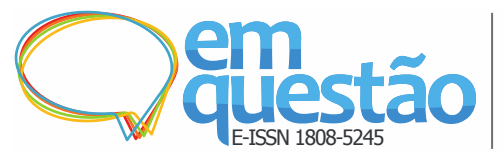

profunda implica na coleta da parcela objetual da realidade, e, portanto, em critérios de seleção:

[...] o objeto deve ter 'REPRESENTATIVIDADE': deve tornar presente alguma coisa, alguém, um fato, um período, um processo.

Essa representatividade [...] implica em dois princípios: a testemunhalidade e a documentalidade.

A testemunhalidade (valor de testemunho) [...] é condição indispensável da musealização de objetos: é necessário que o objeto dê seu testemunho, [...] que seja informante de alguma coisa ou de alguém.

É também condição da musealização a documentalidade, o poder de ensinar ('docere'), de fazer saber. (RÚSSIO, 1984, p. 55, tradução nossa, grifos da autora).

No início da década de 1990, circulam também entre autores brasileiros, textos de autoria do holandês Peter Van Mensch. Embora o autor assinale em sua tese de doutorado a rejeição à noção de objeto como documento, seus trabalhos fundamentaram o artigo Documentação museológica: teoria para uma boa prática, de autoria de Helena Ferrez (1994), o qual colaborou para a disseminação, no Brasil, da ideia do objeto como "portador de dados" - "the object as data carrier".

Fortemente influenciado pelo pensamento de Stránský, Maroević adere à ideia do objeto como documento, incorpora essa visão em seus trabalhos e a mantém, a despeito da discordância de autores como Mensch (1992), que sinaliza uma mudança de posição de Stránský e outros membros do ICOFOM, entre os quais ele próprio:

O objeto do museu - como documento de uma certa realidade, base para a identidade, testemunho de eventos, resultado da habilidade humana, produto da natureza, ou como evidência na qual se baseiam reivindicações e teses científicas no âmbito de disciplinas científicas básicas ou disciplinas acadêmicas - é sem dúvida um elemento da informação de base do conhecimento humano. (MAROEVIĆ, 2000, p. 6, tradução nossa, grifo nosso).

Enquanto na CI, a década de 1990 se caracteriza pela redescoberta de Paul Otlet e Suzanne Briet e o florescimento dos estudos sobre o conceito de 


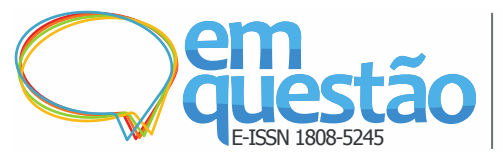

documento, na Museologia ocorre o inverso: a afirmação do objeto como documento perde força e é contestada pelo próprio Stránský, que havia introduzido a questão mais de duas décadas antes. Maroević, entretanto, insiste na definição de musealidade como "[...] a característica de alguma coisa que, em uma realidade, documenta outra realidade [...]", afirmando que "[...] um objeto em um museu é um portador de musealidade [...]" (MAROEVIĆ, 1998, p. 130, tradução nossa). Segundo Vujić e Stublić (2016, p. 38), o autor fizera da Ciência da Informação a base para o trabalho de teorização sobre a Museologia no qual trabalhou de 1983 a 1993 e que resultou no livro Introduction of Museology. Em sua pesquisa de dez anos, baseou-se em princípios estabelecidos por autores como Mensch e o próprio Stránský.

A contribuição do autor foi fundamental para a compreensão do objeto de museu como documento. Membro e colaborador assíduo do ICOFOM, publicou trabalhos em língua inglesa e foi influenciado também por teóricos não vinculados ao Comitê - como estudiosos de cultura material e da área de "Museum Studies", como a inglesa Susan Pearce. Sua obra não apenas contribuiu para a disseminação da Museologia oriunda dos países do Bloco Socialista para além da Cortina de Ferro, mas para as reflexões sobre o objeto como documento:

O valor documental de um objeto de museu é expresso no eixo temporal, porque durante seu tempo de vida o objeto acumula os traços do tempo e eventos em sua estrutura material e formal. Ao mesmo tempo, por sua estrutura material e forma, ele transfere os valores preservados para o futuro. (MAROEVIĆ, 2004, p. 24-25, tradução nossa, grifo nosso).

Em sua tese de doutorado, defendida em 1992 na Universidade de Zagreb, Mensch registra sua discordância de Maroević, professor da mesma instituição, colocando em dúvida se a noção de musealidade como concebida inicialmente por Stránský seria uma propriedade do objeto como documento, e apontando as razões do que considera o equívoco de Maroević: 


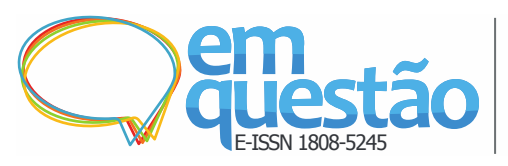

A confusão é, parcialmente, devido ao caráter vago das definições dadas por Stránský, mas também porque suas ideias mudaram. [...] Em 1974, em um folheto referente ao curso de Museologia da Universidade Jan E. Purkinje (Brno), a tarefa da Museologia era descrita como 'perceber e identificar documentos que, em todos os aspectos, melhor representam certos valores sociais'. A esse valor documental Stránský chamou musealidade. (MENSCH, 1992, p. 25, tradução nossa).

De acordo com o autor, embora na década de 1980 Stránský ainda adotasse o termo "musealidade", sua definição de Museologia havia mudado: a missão da disciplina seria, então, interpretar cientificamente a atitude específica do homem em relação à realidade que o leva a reunir e preservar representantes autênticos desses valores. Com isso, a musealidade deixaria de ser uma categoria de valor, e passaria a ser entendida como a própria orientação específica de valor. Para o autor, a obra de Maroević refletiria o "velho conceito de musealidade" (MENSCH, 1992, p. 25, tradução nossa).

Os argumentos de Mensch não resistem ao confronto com textos do próprio Stránský (cf. STRÁNSKÝ, 1985), mas são emblemáticos de uma disputa travada com a CI por alguns membros do ICOFOM na última década do século XX e que será abordada a seguir.

\section{Museologia e Ciência da Informação: um difícil diálogo}

Como abordado no tópico anterior, a década de 1990 marca, no ICOFOM, um ponto de virada no debate sobre o objeto como documento. Diferentemente do Brasil, onde a questão já havia sido abordada quatro décadas antes, os autores ligados ao Comitê pareciam desconhecer até então as reflexões oriundas da Documentação e Ciência da Informação. Em um encontro do ICOFOM realizado em Helsinki, em 1987, Anna Gregorová (1987, p. 123) lamentava o fato de que teóricos da Documentação e da "Informática"14 não reconhecessem o objeto de museu como documento, e que restringissem o conceito aos documentos escritos. 


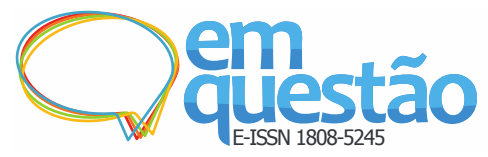

François Mairesse ${ }^{15}$ (2017), entretanto, afirma que a obra de Otlet era conhecida por Stránský - o que é confirmado por um trabalho apresentado em um Simpósio do ICOFOM (cf. STRÁNSKÝ, 1994) - e destaca as semelhanças nos critérios de cientificidade e estratégias adotadas por ambos em suas empreitadas para o reconhecimento da autonomia da Bibliologia e Museologia como disciplinas:

\begin{abstract}
Os escritos do pesquisador tcheco testemunham uma concepção formalista bastante precisa daquilo que deve conter uma disciplina de modo a obter o reconhecimento acadêmico. Uma tal empreitada parece relativamente similar àquela conduzida, quarenta anos antes, por Paul Otlet a fim de desenvolver o bibliologia como ciência do documento [...]. (MAIRESSE, 2017, p. 100).
\end{abstract}

Para os propósitos deste artigo, a semelhança entre os dois autores é menos importante do que o abandono da noção de objeto como documento por Stránský, cuja explicação pode estar nas entrelinhas do mesmo trabalho mencionado por Mairesse. O texto, que critica a abordagem da CI, foi apresentado pelo autor tcheco no Simpósio realizado pelo ICOFOM em 1994 em torno do tema "Objeto-Documento":

O conceito de documentação foi usado pela primeira vez em 1903 por Paul Otlet, um dos fundadores do Instituto Internacional de Bibliografia. De acordo com ele, o termo deveria incluir as Ciências das Bibliotecas, dos Arquivos e dos Museus. Após a Segunda Guerra Mundial, o termo foi suprimido (sic) como resultado da disseminação da Ciência da Informação. Esta disciplina agora usa o termo mais amplo 'fonte de informação' (sic). Embora este termo contemple também objetos materiais, a ciência da informação se concentra apenas naquelas fontes ou meios que servem para fixar os resultados das atividades humanas intencionalmente voltadas à preservação e difusão da informação (sic). Cientistas da informação afirmam não ter um nome para fontes materiais de informação. (STRÁNSKÝ, 1994, p. 48, tradução nossa).

Cabem aqui algumas considerações acerca da crítica de Stránský à CI. Tal como ocorre em vários trabalhos incluídos na mesma publicação, ele não faz uso de citações nem inclui referências, o que dificulta uma análise mais aprofundada e rigorosa ${ }^{16}$. O teor do texto, entretanto, sugere que ao menos uma das fontes pode ter sido a introdução de W. Boyd Rayward à coletânea de 


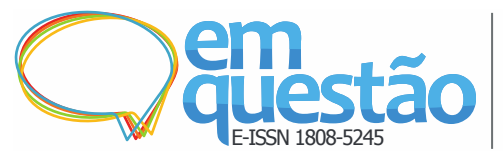

ensaios de Paul Otlet publicada em 1990, a qual menciona várias dos termos e expressões usados por Stránský em sua argumentação:

\begin{abstract}
As ideias de Otlet [...] forneceram a base para uma tentativa de conceituar e desenvolver um novo campo de estudo e pesquisa, que, já em 1903, ele chamou 'documentação'. Ele sugeriu que a documentação deveria se interessar não apenas pelos registros escritos e gráficos, mas também pelos objetos, porque eles têm valor 'documental'. Seu interesse era qualquer coisa que pudesse transmitir informação potencialmente útil, independente de sua forma. Ele foi levado a vislumbrar uma forma de organização documentária cujos níveis e processos assegurariam o fornecimento de informação por meio de serviços revolucionários de informação ou 'agências de documentação'. Estas recorreriam, quando necessário, a textos, imagens ou objetos, como fontes de informação interligadas por métodos comuns, tarefas compartilhadas e acordos formais, cuja existência transformaria bibliotecas em estações em uma rede de informação que alcançaria o mundo inteiro. Sua atividade essencial, estreitamente coordenada com arquivos e museus, seria a informação derivada de toda a imensa variedade de fontes impressas e outras disponíveis. (RAYWARD, 1990, p. 3, tradução nossa, grifo nosso).
\end{abstract}

Se a fonte de Stránský foi mesmo o texto de Rayward, cabe ressaltar a leitura superficial e apressada e, talvez por isso mesmo, a interpretação equivocada. Trata-se de uma clara tomada de posição que sinaliza um confronto da Museologia com a CI que não parece ser recíproco. Algumas das argumentações e críticas parecem desprovidas de fundamentação, até mesmo em virtude da ausência de referências. Segundo o autor, a dificuldade de compreender a diferença entre fonte e documento reside no fato de que a CI "[...] vê o documento como um veículo de informação intencionalmente criado (sic), enquanto uma fonte pode ser qualquer coisa, ou seja, também aquilo que é intencionalmente criado pelo homem." (STRÁNSKÝ, 1994, p. 48, tradução nossa). Outras parecem contradizer a trajetória do próprio autor, segundo o qual, em museus, os termos documento e documentação teriam ocorrido tardiamente, “[...] principalmente em conexão com a documentação e a ciência da informação, ou seja, em décadas recentes e como resultado da computadorização (sic)." (STRÁNSKÝ, 1994, p. 48, tradução nossa). Trata-se de uma afirmativa sem fundamento, sobretudo vinda daquele que é apontado como o primeiro teórico da Museologia a reconhecer o objeto de museu como 


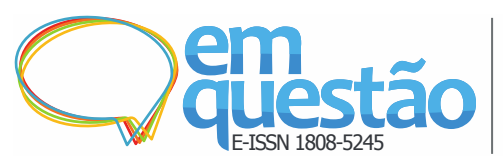

documento. É possível, ainda, apontar inconsistências no interior do próprio texto: após afirmar que o conceito de documentação foi usado por Otlet em 1903, o autor afirma que o termo foi empregado "[...] primeiro na antiga União Soviética e seus países satélites com a campanha 'documentando a construção do socialismo [...]" (STRÁNSKÝ, 1994, p. 48, tradução nossa). Em relação ao termo documento, o autor adverte para a "[...] hegemonia terminológica da ciência da informação [...]", ressaltando que a Museologia é "[...] capaz de chegar à definição do caráter específico da abordagem à realidade da documentação em museus.” (STRÁNSKÝ, 1994, p. 50, tradução nossa)

No mesmo evento que marca o recuo de Stránský e a rejeição da noção de objeto de museu como documento, Maroević reforça sua própria posição, citando um trabalho publicado em 1974 no periódico "Muzeologické sešity" (Cadernos de Museologia), intitulado Metodologické otázky dokumentace současnosti (Questões metodológicas na documentação de hoje) no qual Stránský manifesta sua preocupação com “[...] o valor documental do objeto, [...] fundamento da musealidade.” (STRÁNSKY, 1974 apud $^{17}$ MAROEVIĆ, 1994, p. 118). Três anos mais tarde, em um artigo publicado no periódico Nordisk Museologi, Maroević defenderia a inclusão da Museologia entre as ciências da informação, considerando particularmente o aspecto metodológico:

A metodologia relativamente bem definida das ciências da informação, aplicada com modificações à museologia, ajudará a museologia a definir sistematicamente suas atribuições e objetivos de pesquisa. Em comparação com [...] outros ramos das ciências da informação, podemos ver que a museologia tem características específicas porque seu objeto de pesquisa - o objeto do patrimônio (ou museália em sentido mais restrito) - é uma parte da realidade não transmitida ainda para outra mídia. (MAROEVIĆ, 1997, p. 78, tradução nossa).

Observa, em contrapartida, que, por suas especificidades, a Museologia poderia contribuir para a ampliação do escopo da CI:

Em outras palavras, a museologia lida com o próprio objeto, coleções de objetos e com todas as relações possíveis que o objeto estabelece em um contexto específico. Assim, a museologia frequentemente trata um objeto não apenas como portador ou fonte 
de informação, mas também como um emissor em um processo de comunicação ou um documento de uma realidade possível. Portanto, também trata objetos de museu como elementos que contribuem para o enriquecimento do ambiente humano e que participam da criação de identidades diversas. (MAROEVIĆ, 2000, p. 5-6, tradução nossa).

No final do século XX, Jean Davallon reconhece que, embora o que ele chama "realidade museológica" não tenha aflorado naquele momento, tal realidade não havia se constituído até então um domínio específico reconhecido. Ressalta, ainda, a mobilização de diferentes disciplinas científicas, entre as quais as "Ciências da Informação e da Comunicação"18 para pensar o patrimônio, o que contribuiria para a edificação de um "[...] painel de pesquisas sobre o museu." (DAVALLON, 1997, p. 28, tradução nossa). A posição do autor fica mais clara no trecho que se segue:

O museu ou o patrimônio não são substâncias em si; o que interessa ao pesquisador é sua produção social. Em tal contexto, as discussões sobre o estatuto científico, a autonomia ou o objeto da museologia deixam o domínio da especulação ou da tomada de posição para se tornarem um desafio científico. Isto é evidenciado pelo fato de que a definição de museologia é cada vez menos a de uma ciência do museu e, cada vez mais, uma ciência do tratamento de objetos pelo museu enquanto patrimônio e suporte de informação. Daí o interesse pelas ciências da informação e da comunicação. (DAVALLON, 1997, p. 29, tradução nossa, grifo nosso)

Ressaltando a afirmativa de Maroević (cf. 1994; 2004) de que “[...] a maturidade teórica da disciplina museológica repousa no reconhecimento do valor informativo do objeto, e, consequentemente, de seu estatuto de documento [...]" (MAROEVIĆ, 1989 apud $^{19}$ HERNÁNDEZ HERNÁNDEZ, 2016, p. 87, tradução nossa), a museóloga espanhola Francisca Hernández Hernández subscreve também a opinião de Davallon apresentada acima. Segundo ela, o forte caráter interdisciplinar da Museologia a aproximaria de outros ramos de conhecimento, particularmente das disciplinas envolvidas na "documentação da memória", como a Biblioteconomia e a Arquivologia, em seu papel relacionado ao tratamento de objetos vistos como patrimônio e suporte de informação. "As ciências da informação e da comunicação, nesse caso, seriam convidadas a 


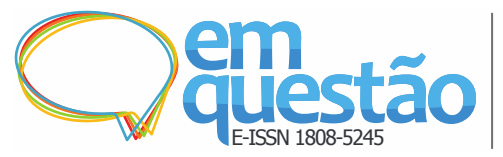

contribuir com os seus próprios campos de conhecimento." (HERNÁNDEZ HERNÁNDEZ, 2016, p. 81, tradução nossa).

Apesar de rejeitar o museu como objeto da Museologia, e de ter abandonado a tese do objeto como documento, Stránský parecia temer exatamente a aproximação do museu e do objeto pela CI:

\footnotetext{
Enquanto a CI opera no nível gnoseológico, a abordagem museológica é focada na ontologia.

Se tivermos sucesso em provar, por novas pesquisas, que esta abordagem é correta e defendermos o caráter específico de nossa abordagem à realidade, isso será benéfico para nós. Mas resolverá apenas parte do problema.

Os conceitos de documento e documentação são bastante vagos. Mesmo se introduzirmos o termo documento de museu, nada mudaria se não definíssemos, simultaneamente as características que nos ajudariam a distinguir este documento de outros. (STRÁNSKÝ, 1994, p. 49, tradução nossa).
}

Vera Dodebei sublinha a necessidade de revisão do conceito de documento de modo a incluir "[...] a intenção de preservação no âmbito da memória social". Ressalta que a transformação de objetos em documentos é intencional (princípio da significação), que a “[...] atribuição de predicáveis ao objeto submetido ao observador [...]" tem caráter seletivo (princípio da virtualidade), e que documentos “[...] não são diferenciados em sua essência, ou seja, não se agrupam em categorias específicas, tais como os exemplos tradicionais: o livro para bibliotecas, o objeto tridimensional para museus e o manuscrito para arquivos." (princípio da unicidade, de particular interesse para os objetivos deste estudo). (DODEBEI, 1997, p. 20)

O reconhecimento da especificidade da Museologia em relação à documentação de seus acervos (cf. SANTOS; GRANATO, 2016) não implica em distinguir os documentos de museu dos demais. Abordar o objeto de museu como documento não significa, necessariamente, defender a busca de qualquer particularidade que o diferencie em essência dos demais documentos, mas simplesmente em reconhecê-lo, tratá-lo e pensá-lo a partir dessa premissa. 


\section{Considerações Finais}

A CI tem assistido a uma ênfase crescente nos estudos sobre o documento desde a década de 1980, os quais têm contribuído para levar adiante e aprofundar as reflexões inaugurais de teóricos da Documentação, como Paul Otlet e Suzanne Briet, que remontam ao início do século XX.

No Brasil, a noção de objeto como documento remonta à década de 1950. Na década seguinte, a questão recebeu atenção de estudiosos do Leste Europeu, entre os quais se destaca o tcheco Zbynek Stránský, cuja obra seria difundida para além dos países do Bloco Socialista nos encontros do Comitê Internacional de Museologia - ICOFOM, fundado em 1977 e vinculado ao Conselho Internacional de Museus - ICOM. Maroević, cujo enfoque europeu é assumido em sua abordagem, destacada como um marco da maturidade teórica da disciplina o reconhecimento do objeto de museu como documento. Essa visão foi hegemônica ao menos até a década de 1980; na última década do século XX, entretanto, alguns teóricos como Peter Van Mensch e o próprio Stránský passaram a rejeitar a noção e a sinalizar uma mudança de rumo na Museologia, enquanto outros, como Maroević, mantiveram a mesma perspectiva.

Duas evidências desse recuo podem ser assinaladas na última década do século XX: a tese de Peter Van Mensch (1992), que contesta o uso por Maroević do conceito de "musealidade" como valor documental, e o Simpósio realizado pelo ICOFOM sobre o tema "Objeto-Documento". No trabalho apresentado no evento, Stránský (1994) manifesta sua discordância da abordagem da CI e sua rejeição à noção do objeto como documento. Essa nova abordagem não é assumida, entretanto, como correção de rumo, mudança de posição ou abandono de um instrumental antigo por outro mais adequado. O autor não explicita uma ruptura com seus trabalhos anteriores, mas os omite, o que sugere um esforço de apagamento desses mesmos trabalhos e do próprio passado da disciplina. Tal apagamento seria posteriormente reforçado pela publicação de duas influentes obras de referência pelo ICOFOM (DESVALLÉES; MAIRESSE, 2010; 2011), 


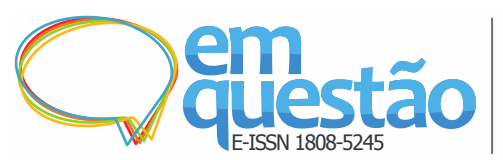

cujo objetivo é padronizar e estabilizar o vocabulário do campo a partir de uma única perspectiva, e que não incluem os verbetes "musealidade" 20 , “informação", "documento" e "documentação".

É difícil precisar as razões para essa guinada. O difícil acesso à obra de Stránský, apontado como a figura central da Museologia e da discussão sobre o objeto como documento no âmbito da disciplina, é um ponto nevrálgico a ser considerado. Em sua maior parte, seus trabalhos foram publicados em tcheco; quanto aos textos em inglês e/ou francês, incluídos em anais de eventos promovidos pelo ICOFOM, podem ser caracterizados como "literatura cinzenta". A tiragem reduzida e circulação restrita dessas publicações comprometeram sensivelmente seu impacto. Como adverte Baraçal (2008), o acesso aos textos originais de Stránský se dá principalmente por meio de outros autores, sobretudo europeus. Ao disponibilizar em sua página na Internet as atas de seus eventos, ainda que tardiamente, o ICOFOM forneceu um considerável material para pesquisas, ainda insuficientemente explorado. Em um texto intitulado A literatura cinzenta se ilumina na web, Freire e Freire (2015) enfatizam o potencial da Internet na ampliação do acesso a esse tipo de documento.

Uma leitura crítica da obra de Stránský e a discussão de suas ideias, no entanto, encontram obstáculos difíceis de transpor. Visto como o fundador da "Museologia Científica" (BRULON, 2017, p. 415) ou "o mestre de Brno" (MAIRESSE, 2017, p. 87) o autor é um mito na disciplina, o que acaba por interditar um debate que poderia ser extremamente fecundo e salutar. Esse debate pode iluminar aspectos relativos à própria concepção da Museologia, questionar alguns pressupostos e reabrir debates aparentemente estabilizados. Estamos falando da mesma coisa quando mencionamos a palavra Museologia? Podemos supor, como fez Paul Veyne em relação ao termo "democracia", que as palavras nos enganam, e que em cada tempo e lugar que se pronuncia uma palavra (como Museologia, por exemplo) podemos estar nos referindo a coisas diferentes? "Nesse caso, as mesmas palavras, as vagas analogias, nos esconderiam diferenças imperceptíveis e enormes, da mesma maneira que as árvores escondem a floresta." (VEYNE, 1984, p. 58). Por longo tempo existiram 


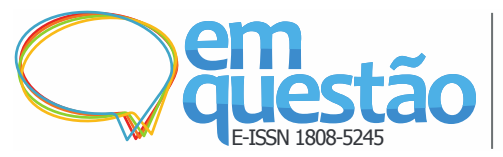

museologias diferentes e incomunicáveis. No Brasil, o termo é empregado desde a criação do Curso de Museus, em 1932 (ver nota 2). É possível falar em uma única Museologia edificada sobre as mesmas bases teóricas e metodológicas e compartilhada em escala mundial? Nesse caso, a partir de que momento? Quando Maroević aponta o amadurecimento teórico da disciplina, refere-se explicitamente a uma perspectiva europeia, como assinala o título de seu livro (MAROEVIĆ, 1998). Stránský teria inaugurado um novo estágio da Museologia quando reconheceu no objeto de museu um documento? Ao abandonar posteriormente a noção, teria fundado um novo estágio? Ou terá criado uma disciplina que se soma a outras, construídas e praticadas em diferentes tempos e espaços, e que só guardam em comum o nome Museologia?

\section{Financiamento}

O projeto de pesquisa no qual se insere este estudo contou com o apoio do Conselho Nacional de Desenvolvimento Científico e Tecnológico (CNPq) através dos Editais Universais 14/2011 (fase 1) e 14/2013 (fase 2, a partir de 2013).

\section{Referências}

BARAÇAL, Anaildo. O objeto da Museologia: a via conceitual aberta por Zbynek Zbyslav Stránský. 2008. Dissertação (Mestrado em Museologia e Patrimônio) - Universidade Federal do Estado do Rio de Janeiro, Rio de Janeiro, 2008.

BRASIL. Decreto no 16.078, de 13 de julho de 1944. DF, 1944. Diário Oficial [da] União, Brasília, p. 12474, 15 jul. 1944. Seção 1.

BRIET, Suzanne. Quest-ce que la documentation? Saint-Denis, Paris: Documentaires, Industrielles et Techniques, 1951.

BRULON, Bruno. Provocando a Museologia: o pensamento geminal de Zbynek Z. Stránský e a escola de Brno. Anais no Museu Paulista, São Paulo, v. 25, n. 1, p. 403-425, 2017.

BUCKLAND, Michael Keeble. What is a Document? Journal of American Society for Information Science, Hoboken, v. 48, n. 9, p. 804-809, 1997. 


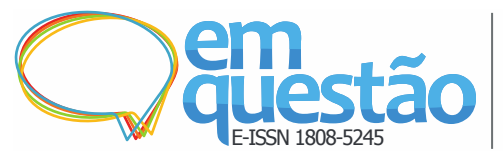

O Objeto de museu como documento: um panorama introdutório

Maria Lucia de Niemeyer Matheus Loureiro

CERAVOLO, Suely Moraes. Delineamentos para uma teoria da Museologia. Anais do Museu Paulista, São Paulo, v. 12, p. 237-268, 2004.

CORMERAIS, Franck et al. Les SIC à l'épreuve du digital et des Humanités : des origines, des concepts, des méthodes et des outils. Revue Française des Sciences de l'Information et de la Communication, Pessac, n. 8, 2016.

DAVALLON, Jean. L'État de la Museologie en France. Icofom Study Series, Paris, n. 28, p. 25-31, 1997.

DESVALLÉES, André; MAIRESSE, François (Dir.). Concepts clés de muséologie. Paris: Armand Colin, 2010.

DESVALLÉES, André; MAIRESSE, François (Dir.). Dictionnaire encyclopédique de muséologie. Paris: Armand Colin, 2011.

DODEBEI, Vera Lucia Doyle. O sentido e o significado do documento para a memória social. Tese (Doutorado em Comunicação) - Universidade Federal do Rio de Janeiro, Rio de Janeiro, 1997.

FERREZ, Helena Dodd. Documentação museológica: teoria para uma boa prática. Cadernos de Ensaios, Rio de Janeiro, n. 2, p. 64-73, 1994.

FREIRE, Gustavo Henrique; FREIRE, Isa Maria. A literatura cinzenta se ilumina na web. Informação \& Sociedade: Estudos, João Pessoa, v. 25, n. 2, p. 5-6, 2015. Editorial.

FROHMANN, Bernd. Revisiting "What is a document". Journal of Documentation, Bingley, v. 65, n. 2, 2009, p. 291-233.

GREGOROVÁ, Anna. Interdisciplinarity in Museology: Anna Gregorova. MuWop: Museological Working Papers, Stockholm, v. 2, p. 33-36, 1981.

GREGOROVÁ, Anna. [Basic Paper]. In: SYMPOSIUM MUSEOLOGY AND MUSEUMS, 1987, Helsinki. Proceedings... Helsinki: ICOM 1987. p. 121-129. (ICOFOM Study Series, 12).

HERNÁNDEZ HERNÁNDEZ, Francisca. Documentary Sources of Museology: Reflections and perspectives. ICOFOM INTERNATIONAL SYMPOSIUM: Museology exploring the concept of MLA (Museums-Libraries-Archives, 38., 2015, Tsukuba, Japan. Proceedings...Tsukuba: University of Tsukuba, 2016. p. 81-93. (ICOFOM Study Series, 44).

HOOPER-GREENHILL, Eilean (Org.). Museum, media, message. London: Routledge, 2004. 


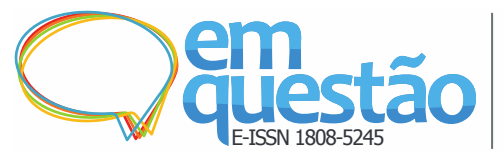

O Objeto de museu como documento: um panorama introdutório

Maria Lucia de Niemeyer Matheus Loureiro

JELÍNEK, Jan. MuWop: we wish you well. MuWop: Museological Working Papers, Stockholm, n. 1, p. 4-5, 1980.

LORENTE, Jesus Pedro. Manual de historia de la Museologia. Gijón: Trea, 2012.

LUND, Niels Windfeld Lund. Document Theory. ARIST: Annual Review of Information Science and Technology, Hoboken, v. 43, n. 1, p. 1-55, 2009.

MAIRESSE, François. Zbyněk Stránský e a Bibliologia. In: SOARES, Bruno Brulon; BARAÇAL, Anaildo Bernardo (Orgs.). Stránský: uma ponte BrnoBrasil / Stránský: a bridge Brno-Brazil. Paris: ICOFOM, 2017. p. 87-100.

MAROEVIĆ , Ivo. Introduction to Museology: the european approach. Munich: Verlag, 1998.

MAROEVIĆ , Ivo. Museology as a discipline of Information Science. Nordisk Museologi, Oslo, n. 2, p. 77-92, 1997.

MAROEVIĆ, Ivo. Museology as a field of knowledge. Cahier d'études / Study Series, Courtrai, v. 8, p. 5-7, 2000.

MAROEVIĆ, Ivo. The museum message: between the document and the information. In: Hooper-Greenhill, E. (Ed.). Museum, media, message. London: Routledge, 2004. p. 23-36.

MAROEVIĆ, Ivo. The Museum Object as a Document. SYMPOSIUM OBJECT-DOCUMENT. 1994. Beijing. Proceedings... Beijing: ICOM, 1994. p. 113-119. (ICOFOM Study Series, 23).

MENSCH, Peter Van. Towards a methodology of museology. Tese (Doutorado em Museologia) - University of Zagreb, Zagreb, 1992.

MESQUITA, Espírito Santo. Prefácio. In: TRIGUEIROS, F. dos Santos. Museus: sua importância na educação do povo. Rio de Janeiro: Irmãos Pongetti, 1956. p. i-iii.

MEYRIAT, Jean. Document, documentation, documentologie. Schéma et Schématisation, Noyers-sur-Serein, v. 14, p. 51-63, 1981.

ORTEGA, Cristina Dotta. A Documentação como uma das origens da Ciência da Informação e base fértil para sua fundamentação. Brazilian Journal of Information Science, Marília, v. 3, n. 1, p. 3-34, 2009.

OTLET, Paul. The Science of Bibliography and Documentation. In: RAYWARD, W. Boyd (Ed.). International organization and dissemination 


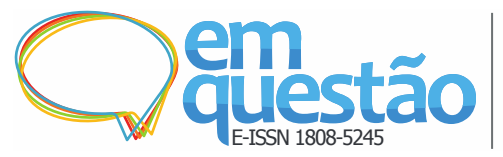

of knowledge: selected essays of Paul Otlet. Amsterdam: Elsevier, 1990. p. 7186.

OTLET, Paul. Traité de Documentation: le livre sur le livre. Bruxelles: Mundaneum. 1934.

POBLACIÓN, Dinah Aguiar. Literatura cinzenta ou não convencional: um desafio a ser enfrentado. Ciência da Informação, Brasília, v. 21, n. 3, p. 243246, 1992.

RAYWARD, Warden Boyd. Introduction. In: RAYWARD, Warden Boyd (Ed.). International organization and dissemination of knowledge: selected essays of Paul Otlet. Amsterdam: Elsevier, 1990. p. 1-10.

REAL, Regina Monteiro. O museu ideal. Belo Horizonte: Tipografia da Faculdade de Direito da Universidade de Minas Gerais e do Centro Regional de Pesquisas Educacionais, 1958.

RÚSSIO, Waldisa. Interdisciplinarity in museology: Waldisa Russio. MuWop: Museological Working Papers, Stockholm, n. 2, p. 56-57, 1981.

RÚSSIO, Waldisa. [Sem título]. SYMPOSIUM COLLECTING TODAY FOR TOMORROW - COLLECTER AUJOURD'HUI POUR DEMAIN. 1984, Leiden. Proceedings... Leiden: ICOFOM, 1984. p. 51-59. (ICOFOM Study Series, 6).

SÁ, Ivan Coelho de. História e Memória do Curso de Museologia: do MHN à UNIRIO. Anais do Museu Histórico Nacional, Rio de Janeiro, v. 39, p. 10-48, 2007.

SANTOS, Cláudia Penha; GRANATO, Marcus. A documentação museológica e as coleções de Ciência e Tecnologia: identificando especificidades.

ENCONTRO NACIONAL DE PESQUISA EM CIÊNCIA DA

INFORMAÇÃO, 17., 2016, Salvador. Anais... Salvador: ANCIB, 2016.

SANTOS JUNIOR, Roberto Lopes. Análise da terminologia soviética "Informatika" e da sua utilização nas décadas de 1960 e 1970. ENCONTRO NACIONAL DE PESQUISA EM CIÊNCIA DA INFORMAÇÃO, 11., 2010, Rio de Janeiro. Anais... Rio de Janeiro, 2010.

SCHREINER, Klaus. Criteria on the place of Museology in the system of sciences. MuWop: Museological Working Papers, Stockholm, v. 1, p. 39-41, 1980 .

STRÁNSKÝ, Zbyněk Zbyslav. Object - document. Or do we know what we are actually collecting? SYMPOSIUM OBJECT-DOCUMENT. 1994, Beijing. Proceedings... Beijing: ICOM, 1994. p. 47-51. (Icofom Study Series, 23). 
STRÁNSKÝ, Zbyněk Zbyslav. Originaux contre substitutes. SYMPOSIUM ORIGINAUX E OBJETS SUBSTITUTIFS DANS LE MUSEES. 1985, Zagreb. Proceedings... Zagreb: ICOFOM, 1985. p. 103-113. (ICOFOM Study Series, n. 9).

TRIGUEIROS, Florisvaldo dos Santos. Museus: sua importância na educação do povo. Rio de Janeiro: Irmãos Pongetti, 1956.

TRIGUEIROS, Florisvaldo dos Santos. O Museu - órgão de documentação. Cadernos AABB, Rio de Janeiro, n. 11, 1955.

VEYNE, Paul. Os gregos conheceram a democracia? Diógenes, Brasília, n. 6, p. 57-82, 1984.

VUJIĆ, Žarka; STUBLIĆ, Helena. Museology as part of information and communication sciences in Croatia: a view on a thirty-year-long experience.

Icofom Study Series, Paris, v. 44, 2016, p. 37-45.

\title{
The Museum object as a document: an introductory overview
}

\begin{abstract}
The article presents an overview of the discussions about the object as a document in Information Science and Museology, identifies and analyzes convergent and divergent issues in the two disciplines. Exploratory study based on bibliographic research. It is emphasized the contribution of the Information Science, which recognized the object as a document decades before the discussions promoted by Museology. The discussions around the museum object as a document in the field of Museology (considered by some authors the starting point of theoretical maturity of the discipline) and the subsequent rejection of the notion are approached. Attempts to obliterate the past of Museology by some of its influential theorists are noticed.
\end{abstract}

Keywords: Document. Museum object. Information Science. Museology.

Recebido: $22 / 03 / 2018$

Aceito: $11 / 07 / 2018$

\footnotetext{
${ }^{1}$ Ivo Maroević (1937-2007) fundou, em 1984, a Cadeira de Museologia no Departamento de Ciências da Informação da Universidade de Zagreb (HOOPER-GREENHILL, 2004, p. 14).

${ }^{2}$ No Brasil, o termo Museologia era adotado desde 1932, ano da criação do Curso de Museus, que adquire status de curso superior em 1944, através do Decreto 16.078. Conforme o parágrafo 32 do Decreto, "O Curso será ministrado por professores, designados pelo Diretor do Museu Histórico Nacional mediante proposta do Coordenador do Curso, dentre especialistas em museologia, nacionais ou estrangeiros, servidores do Estado ou não." (BRASIL, 1944, grifo nosso). Com base no Regimento aprovado em dezembro de 1974 e homologado pelo Ministério da Educação e Cultura (MEC) em janeiro do ano seguinte, Ivan Coelho de Sá (2007, p. 34) destaca a concepção "ampla e engajada" do Curso, que priorizava a formação em Museologia "encarada num contexto interdisciplinar". O documento conjugava
} 
o aprimoramento de processos e técnicas inerentes ao fazer museológico e "pesquisa no campo da Museologia", incentivando a divulgação de seus resultados. Na década de 1950, a museóloga Regina Monteiro Real já se referia à Museologia como "[...] uma ciência nova que vem sendo posta em evidência há apenas uns trinta anos." (REAL, 1958, p. 5).

3 A afirmação é ratificada por Mensch (apud CERAVOLO, 2004, p. 244), que aponta a carência de trabalhos de síntese, indicando uma "produção intelectual esparsa e de difícil acesso". MENSCH, Peter Van. Towards a methodology of museology. Tese (Doutorado em Museologia) - University of Zagreb, Zagreb, 1992.

${ }^{4}$ A expressão "literatura cinzenta" é utilizada para nomear documentos de circulação mais restrita, como “[...] relatórios de todos os tipos (Internos, institucionais, técnicos, de pesquisa, de comissões e outros), as comunicações apresentadas em eventos, os anais e atas de reuniões, as conferências, pre-prints, publicações oficiais, teses, traduções, patentes, normas etc." (POBLACIÓN, 1992, p. 244).

${ }^{5}$ Zbynek Stránský (1926-2016) criou na década de 1960 uma Escola de Museologia na Universidade J. E. Purkyne, em Brno, antiga Tchecoslováquia.

${ }^{6}$ O relato apresentado nesta seção privilegia o objeto de museu. Para um panorama mais detalhado sobre as reflexões sobre o documento na CI, ver Ortega (2009).

${ }^{7}$ O artigo foi traduzido para o inglês e publicado em 1990 em uma coletânea organizada por W. Boyd Rayward (OTLET, 1990).

${ }^{8}$ FAYET-SCRIBE, S. Histoire de la documentation en France: culture, science et technologie de l'information, 1895-1937. Paris: CNRS Editions, 2001. Apud Ortega (2009).

${ }^{9} \mathrm{O}$ autor se refere ao Muséum National d'Histoire Naturelle, fundado em Paris no final do século XVIII e ao Musée National des Arts et Traditions Populaires, fundado, também em Paris, por Georges-Henri Rivière em 1937 e fechado ao público em 2005.

${ }^{10}$ Žarka Vujić e Helena Stublić (2016, p. 37-38), professores da Universidade de Zagreb, enfatizam o papel pioneiro do museólogo Antun Bauer que, nos anos 1960, abordou o objeto de museu como "objeto de conhecimento" e ressaltou o significado documental dos artefatos, sugerindo uma proximidade com o conceito de "musealidade", que se tornaria central para a museologia no final da década. Acrescentam ainda que as ideias de Bauer sobre Museologia baseavam-se essencialmente na documentação, o que as aproximava da documentação e biblioteconomia.

${ }^{11}$ STRANSKY, Zbyněk Zbyslav. Pojam muzeologije. Muzeologija, Zagreb, v. 8, n. 40, p. 73, 1970. Apud Maroević (2004, p. 24).

${ }^{12}$ STRANSKY, Zbyněk Zbyslav. Metologicke otazky dokumentace soucasnosti. Museologické sešity, Brno, v. 5, p.13-43, 1974. Apud Schreiner (1980, p. 39).

${ }^{13}$ Waldisa Russio (1935-1990) fundou, em 1978, um Curso de Especialização em Museologia na Fundação Escola de Sociologia e Política de São Paulo (FESPSP).

${ }^{14}$ Cabe ressaltar aqui que, ao utilizar o termo Informática (Informatics), a autora (oriunda da antiga Tchecoslováquia) refere-se provavelmente à Ciência da Informação, e não à disciplina que estuda o processamento de informação por meio de dispositivos eletrônicos e sistemas computacionais. A denominação "Informática" (ou "Informátika") foi adotada a partir de 1966 na antiga URSS e países do bloco socialista para designar a disciplina que no Ocidente já era denominada "Ciência da Informação". A nomenclatura foi consolidada por Alexander Mikhailov (1905-1988) e colaboradores (SANTOS JÚNIOR, 2010).

15 Professor da Universidade Paris 3, atual Presidente do ICOFOM.

${ }^{16}$ A carência ou incorreção das fontes citadas por Stránský é apontada também por outros autores, como Baraçal (2008, p. 12) e François Mairesse (2017, p. 93).

${ }^{17}$ STRANSKY, Zbyněk Zbyslav. Metologicke otazky dokumentace soucasnosti. Museologické sešity, Brno, v. 5, p.13-43, 1974. Apud Maroević (1994).

18 As "Ciências da Informação e da Comunicação" situam-se, na França, no cruzamento de duas disciplinas que constituem "entidades distintas" no mundo anglo-saxão (CORMERAIS et al, 2016). Teóricos franceses reconhecidos pela Museologia, entre os quais o próprio Jean Davallon, atuam nesse campo.

${ }^{19}$ MAROEVIĆ, Ivo. The museum message: between the document and the information. In: HooperGreenhill, E. (Ed.). Museum, media, message. London: Routledge, 2004. p. 23-36. Apud Hernández Hernández (2016).

${ }^{20} \mathrm{O}$ termo musealidade figura em ambas as obras como termo correlato ou derivado nos verbetes museal, musealização, museologia e museu. 